\title{
Emotional Intelligence and the Identity Negotiation of a Racial Minority Group in a Majority School Context
}

\author{
Jacobus G. Maree \\ Maria M. Meijer \\ University of Pretoria
}

\begin{abstract}
Address correspondence to Professor Jacobus G. Maree, Faculty of Education, University of Pretoria, 0001 Pretoria, South
\end{abstract} Africa.E-mail: Kobus.Maree@up.ac.za.

This article describes the possible impact of emotional intelligence on identity negotiation of a racial minority group in a majority school context. The study investigated the adjustment and functioning of racial minority groups in majority school contexts, as well as the identity negotiation associated with it, and determined whether there is a correlation between the former and the Emotional Intelligence (EI) of the participants. Participants were 16 black and 21 white learners attending two schools where they were in the minority (mean age $=16.23$ years; $S D=1.49$ years). The learners attended Grades 9-12. Data were first organised, after which themes and patterns were identified, and the data appraised and categorised (Creswell, 2007), after which a comparison was drawn between the identified categories of existing knowledge. Findings suggest that racial integration in both high schools actually occurred in name only; most participants chose to mingle within their own racial groups and the black participants in particular were exposed to racism, discrimination and prejudice on a regular basis. Despite the necessary steps taken and implemented by government in order to oppose racism in the country and promote racial integration in schools, it seems that the consequences of apartheid remain for the foreseeable future.

\section{Keywords: Emotional intelligence, identity negotiation, racism, minority group, school context}

Since 1994 when previously white schools in South Africa were expected to open their doors to learners from diverse groups and backgrounds, desegregation has been mainly a one-way process, with learners from disadvantaged racial groups demanding access to schools that were in the past reserved for white learners only. Despite the fact that many former (especially more well-off) white schools still have a majority of white learners, the influx of black learners (especially in less well-off schools) led in many cases to the migration of white learners from these schools (Dolby, 2002; Tihanyi, 2007). The current reality in many desegregated schools is therefore that one racial group constitutes by far the minority and that learners belonging to such a group are not necessarily allowed to negotiate their own identity within a majority school context.

Our article deals with topical issues in post-apartheid South Africa: integration in schools is vital for the creation of a non-racist society. Erikson (1968) and Wakefield and Hudley (2007) were of the view that identity was as a core developmental task during adolescence since adolescents acquire a self-image during that period. For instance, they seek a greater agreement between their true self and ideal self, compared to their peers who do not manage to negotiate their identity successfully (Akos \& Ellis, 2008). Adolescents are also more inclined towards critical and abstract thinking-which also reflects in their superior moral reasoning compared to younger children. Although an individual's identity is made up of various components (e.g., age, gender, sexuality, etc.), race and ethnicity can be regarded as core components (Bennett, 1999; Erasmus, 1999; Machaisa, 2004).

\section{Sources of Racial/Ethnic Identity}

Individuals are not born with a racial ethnic identity; they define themselves in terms of racial ethnic membership into a specific group and these perceptions of the self develop over time through interaction with others (Grantham \& Ford, 2003). According to Cushner, McCelland and Safford (2006), the concept of "racial minority group" refers to a social group that occupies an inferior position in a society. A racial majority group is regarded as one that is privileged and has more resources and rights (Kendall, 1997). The negotiation ${ }^{1}$ of a positive racial ethnic identity offers an individual the opportunity to personally redefine membership of a racial ethnic group and to refuse to allow society to define it for her $^{2}$. In the previous social dispensation in South Africa, white individuals (especially Afrikaans-speaking ones) were considered a high-status group, while black individuals were deemed a socially inferior group (Bornman in Polson, 1996). Machaisa (2004) believed that this categorisation still occurs in many white schools and that integration in South African schools is not necessarily problem-free (Msila, 2005; Polson, 1996).

Instead of becoming models of integration in society (Jansen, 2004), white dominance (which characterised artheid teaching) is still reflected in the majority of (formerly white) South African schools (regardless of whether white or black learners being the minority). Consequently, racism (Vandeyar, 2007) and the suppression of black identity is still visible (Machaisa, 2004). These factors can cause much stress and may leave learners feeling helpless, estranged from their peer group, and unhappy (Machaisa, 2004; Polson, 1996). This may in turn have a direct effect on their school performance (Maree \& Ebersöhn, 2002) since the actualisation of core facets of learners' El may be hampered. This study investigated the pos- 
sible correlation between the El of a racial minority group and their identity negotiation, adjustment and functioning.

$\mathrm{El}$ is represented by a wide range of interconnected emotional, personal and social competencies that influence a person's ability to cope with daily demands (Bar-On, Tranel, Denburg \& Bechara, 2003). According to Bar-On (2006), the optimally functioning, successful and emotionally healthy individual is someone with an adequate degree of El. It is the individual's capacity to recognise, understand and regulate her own emotions; to recognise and understand the emotions of others; to establish and maintain relationships with others; to display problem-solving skills and to be self-motivating so as to handle situational demands successfully.

\section{A Privileged Experience}

During the different phases of our careers (as educators and educational psychologists), we have become aware of the challenges that (especially black) learners often have to deal with in diverse school contexts. For example, we met a black adolescent who lived with her mother at the mother's white employer. She had developed an aversion to her appearance (especially her skin colour) and repeatedly expressed the wish to be "white". She even slept with a bag covering her head in an attempt to straighten her hair, because they (her peer group) always have the most beautiful, soft, long hair while my own stays this short . . . and since I was small I have always wished for such beautiful, soft, long hair. Our interaction and conversations with white learners also confirmed that peer group relations within diverse school contexts were not always satisfactory. These learners indicated for example that they felt threatened by the black learners, inter alia because they were different ... . part of another culture, and because they are simply put through and do not really belong here.

By contrast, we learned of a black girl and boy who were elected as countrywide winners of the Afrikaanse Taal and Kultuurvereniging's (ATKV) public speaking competition and concluded that one cannot simply assume that all black learners struggle to adjust and to function successfully in white school contexts. Both these learners were enrolled at prestigious Afrikaans schools in the eastern part of Tshwane at that stage, and their adjustment and functioning in those schools seemed to be very successful. The high school learner was vice-head boy of his school and editor of the school newspaper, while the primary school girl excelled in the cultural field. The circumstances of both learners differed dramatically from those of their peer group in the respective schools. The girl and her mother lived in with the latter's employer (she walked five kilometres to school every day), while the boy grew up in an orphanage.

We started wondering why these two learners managed to function successfully (and even happily) in these contexts, while other learners were struggling with great effort through their school careers without ever achieving their potential. We were also interested in the way in which white learners (who despite the migratory trend, "remained behind" in predominantly black schools) adjusted and functioned in such schools, and how they went about negotiating their own identity within these school contexts.

In view of our strong interest in El, we could not help starting to speculate whether there was perhaps a correlation between the El of members of racial minority groups and their functioning in majority school contexts, since El concerns inter alia a person's ability to deal with environmental demands and pressures (Bar-On in Van Rooyen, 2002). While the adjustment and func- tioning of black learners in white school contexts are described in the literature in a fair amount of detail, there seems to be inadequate information about the identity negotiation, adjustment and functioning of white learners within black school contexts. In addition, we as authors could trace no research in which the El of members of racial minority groups could be related to their identity negotiation, adjustment and functioning in majority school contexts.

\section{Cultural Ethics of Segregated Schools}

The integration of black learners in white schools implied that learners from disadvantaged backgrounds had to adapt to the norms and cultures of the schools in advantaged communities (Machaisa, 2004; Msila, 2005; Vandeyar, 2007). A possible reason for this could be that a school wished to "incorporate" new cultures, yet without having them interfere with its existing standards and cultural ethos (Machaisa, 2004). Despite attempts in former white schools to "respect" learners' diverse cultures, learners are mostly expected to "fit in with" Western cultural standards.

Thus acculturation (adjustment towards the mainstream culture) and enculturation (adjustment towards the dominant racial-ethnic culture) take place, and, inevitably, certain aspects of the own culture (for example language and religion) are abandoned in favour of aspects of other cultures (van Ryneveld-Grové in Kriel, 2000). The assimilation approach therefore does not only attempt to change the identity of black learners, but it also conveys a subtle message, namely that the latter's identity is inferior (Nieto, 2000).

\section{Social Climate Issues}

In a study by Kriel (2000) that both black and white adolescents experience integration as largely negative. The relationship among learners was named as the most important reason for this, and both groups remarked that there was little or no interaction among them. They indicated that background differences, group pressure and the objections of their parents inhibited them from mingling freely with members of other racial groups. These findings concur with the findings of other studies with similar objectives carried out in South Africa (Machaisa, 2004; Polson, 1996).

Social isolation can also occur in the white school context through a lack of the necessary language and social skills that are required for effective communication in a different/new racial-ethnic context. It can also be the result of racism, discrimination and prejudice-all of which black learners have to deal with on a regular basis.

\section{Racism, Discrimination and Prejudice}

Black learners came to the white schools with much anticipation, expecting to be welcomed as equals and friends in the spirit of the "New South Africa." However, many of them were disillusioned soon and felt rejected (Harber, 1998; Kriel, 2000; Machaisa, 2004). Black adolescents indicate that they are confronted by racism, discrimination, stereotyped attitudes as well as physical and verbal abuse on a daily basis. Research shows a high correlation between the former and a lower self-image, increased symptoms of depression, escalating behavioural problems and growing emotional need. Even the mere anticipation of discrimination is related to these symptoms (Wakefield \& Hudley, 2007). 


\section{Different Languages}

The languages of members of racial minority groups are generally not used or offered in majority school contexts, especially not in former white schools, with the result that they do not enjoy the same tuition and training opportunities of majority groups (Du Plooy \& Swanepoel, 1997).

\section{Racial-Ethnic Identity Negotiation}

White racial identity is generally considered an indiscernible yet privileged identity formed by many years of domination of non-white groups (McDermott \& Samson, 2005). "Whiteness" is in most literature seen as synonymous with "being privileged", despite the fact that more recent empirical studies strive to portray white racial identity as a complex rather than a monolithic identity.

Most definitions of white racial identity therefore include the following characteristics (McDermott \& Samson, 2005): it is often invisible or taken for granted; it is based on social and economic privilege; it carries great significance and is extremely context-bound. In the same way that they often do not 'observe' their own race, many white individuals are unaware of the relationship between their racial identity and the power and opportunities offered to them.

\section{Racial-ethnic Identity Negotiation Among White Individuals}

Despite enormous variations of power among white individuals related to socio-economic status, gender, sexuality and other factors, white power can rarely be isolated from being privileged. Suchet (2007) and Cushman (2000) considered whiteness as firstly a political indicator of socio-economic power that is maintained by the power relations and institutions that constitute society. The white learners with a history of socio-political power (see Dolby, 2001) felt trapped, angry and fearful by the enrolment of black students at the same schools. They were of the view that they were being pushed out of "their" own school. These learners reacted to their new reality with what McCarthy et al. (in Dolby, 2001) refer to as anger and umbrage. By negating the other and deploying moral evaluation and emotion strategically (McCarthy et al. in Dolby, 2001), they managed to position themselves as the victims. The resentment expressed by white learners is propped up by fear: a fear that whiteness is no longer in control in South Africa, that the "other" group now constitutes the focal point. For example, the white learners in Dolby's (2001) study showed a great fear of black violence and black economic progress and indicated that they wished to leave South Africa. According to Dolby (2001) this may be regarded as a way in which these learners are trying to escape the "blackness" around them and re-establish their white identity (and the privileges associated with it) as part of a "white nation".

\section{Racial-ethnic Duals}

According to Akos en Ellis (2008), black individuals mostly regard race and ethnicity as a central part of their identity (contrary to their white peers), which creates a variety of challenges. Black learners are more inclined to encounter obstacles in negotiating a healthy racial-ethnic identity, inter alia as a result of their exposure to racism (Norton \& Baker, 2007; Vandeyar, 2007; Zirkel, 2004). Meaningful relationships between racial ethnic identity negotiations and perceptions of prejudice were also observed (Alvarez, Juang \& Liang, 2006) and correlations between perceptions of discrimination and the subsequent in- crease in racial-ethnic identity were demonstrated in various longitudinal studies (Pahl \& Way, 2006; Sellers \& Shelton, 2003).

\section{The Role of the School in Racial-ethnic Identity Negotiations}

It is generally accepted that racial-ethnic identity is socially constructed and negotiated (Jackson \& Heckman, 2002). Individuals are moulded as racial-ethnic beings to view themselves and the world in a particular way. In the same way, the identity negotiations of individuals are affected by the perceptions and social constructions of others; in other words, there is an exchange of cultural values, norms, beliefs, orientations and world views that contribute to the individual's construction of a self image (Jackson, Martin \& Nakayama in Jackson \& Heckman, 2002). The ways in which individuals understand themselves and their racial-ethnic characteristics, as well as the social contexts within which they find themselves, therefore have a mutual effect on one another (Chavous et al., 2003). The school environment can be considered one of these contexts. In our opinion, the identity negotiation, adjustment and functioning of an individual is potentially related to his or her El.

\section{The Significance of El}

Various researchers (e.g., Bar-On, 1997; Taylor, 2001) believed that an individual who is emotionally intelligent is better able to regulate emotions effectively and to reveal effective coping strategies, and therefore they will probably enjoy better psychological health. El is related to a range of factors by means of which the chances of success in life can be enhanced (Bar-On, 1997; Mayer, Caruso, \& Salovey, 2000; Saklofske, Austin \& Minski, 2003). For example, research indicates that individuals with a high El display higher levels of effective stress management, problem solving and adequate mood regulation (Bar-On, 2001; Nikolaou \& Tsaousis, 2002). We wanted to use the present study to explore this relationship further.

\section{Goal of the Study}

The aim of this research was to investigate the adjustment and functioning of racial minority groups in majority school contexts, as well as the identity negotiation associated with it, and to determine whether there is a correlation between the former and the El of the participants. Our specific research question was: What is the possible correlation between the El of racial minority groups and their identity negotiation, adjustment and functioning in a majority school context ${ }^{3}$ ? Secondary research questions included:

- In which possible ways is the identity negotiation of racial minority groups affected by a majority school context?

- What possible impact does the experience of a majority school context have on the development and behaviour of racial minority groups?

- What possible role do El skills play in the identity negotiation, adjustment and functioning of racial minority groups within a majority school context?

- What additional factors play a role in the identity negotiation, adjustment and functioning of racial minority groups within a majority school context? 


\section{Method}

\section{Research Design}

A case study design was implemented in this study. The investigation was based on an interpretivist paradigm (Denzin \& Lincoln, 1998). The research design was of a QUALITATIVE-quantitative nature (Creswell, 2007), but for the purposes of this article the focus will be on qualitative data analysis only.

\section{Participants and Context}

Purposefully selected learners (non-random sampling) at two schools (hereafter referred to as "High School A" and "High School B"), where white and black learners respectively are in the minority (6\% enrolment white and 9\% enrolment black) participated in the study. The total of 37 learners involved in the study attended Grades 9-12 (blacks $=16$, whites $=21$; males $=$ 17 ; females $=20$, mean age $=16.23, S D=1.49$, ) members of a racial minority group) were identified as the target population, since these learners are in the midst of the critical development phase of adolescence and have already gained an adequate amount of experience in the high school context.

\section{Data Collection}

El was measured using the Emotional Quotient Inventory: Youth Version (EQ-i: YV) (Bar-On \& Parker, 2000). The four-factor structure of the EQ-i: $Y V$ (Interpersonal, Intrapersonal, Stress Management and Adaptability scales) emerged through an exploratory factor analysis of the total normative sample. Internal reliability (Cronbach's $\alpha$ ) varied between 0.67 and 0.90 (Bar-On \& Parker, 2000). The test-retest reliability coefficients of the $E Q-i: Y V$ ranged between 0.77 and 0.89. Guidelines for the interpretation of El scores are provided in Table 1. However, since the scale has not yet been standardised on a representative South African sample of learners, the results of our study should still be regarded with the necessary caution.

Qualitative data were gathered by means of focus group interviews, semi-structured individual interviews (with participants and educators), observation of participants during interviews, field notes and reflective journals (researchers as well as participants). Verbal responses to the semi-structured questions were recorded on tape. Trustworthiness issues were considered as in Table 2. In the study in hand, the use of the concepts "racial minority group" and "majority group" depended on the numerical value of the groups within the school context in which they were studied.

\section{Procedure}

Written permission was obtained from the Department of Education, the relevant schools, as well as the participants and their teachers. The learners who gave their informed assent completed the El questionnaire (the EQ-i: $Y V$ ) during school time, according to the instructions provided by Bar-On and Parker (2000). Subsequently six white learners (three boys and three girls) were selected (for both the focus group and the individual interviews) from the black school context and six black learners (three boys and three girls) from the white school context on the grounds of the scores that they had achieved in the questionnaire mentioned. Informed consent was obtained from the participants and their parents, and confidentiality was maintained throughout.

\section{Data Analysis}

Documented data were first of all organised and categories, themes and patterns were identified. The data were appraised and categorised (Creswell, 2007), after which a comparison was drawn between the identified categories of existing knowledge (literature) on $\mathrm{El}$ and the identity negotiation, adjustment and functioning of racial minority groups in majority school contexts. The factors that collectively comprise the El test (Bar-On \& Parker, 2000) (interpersonal, intra-personal, stress management, general mood and adaptability) were used as predetermined categories which we then used to analyse our data (deductive analysis) (McMillan \& Schumacher, 2001). Additional themes (that emerged from the data but did not correspond with these themes) were classified apart from the other themes.

\section{Results}

The themes that emerged from the semi-structured interviews with the participants and teachers of High Schools A and $\mathrm{B}$ are summarised in Table 3.

\section{Discussion}

\section{Negotiating the Identity of a Racial Minority Group within a Majority School Context}

The racial-ethnic identity negotiation of the white participants (in the black school context) was investigated ${ }^{4}$ on the basis of the racial identity development theories of Helms (1995) and Phinney (1989), while the racial-ethnic identity negotiation of the black participants (in the white school context) was investigated on the basis of the racial identity development theories of Cross $(1971,1991)$ and Sue and Sue (1990).

Despite being in a black, English school context, the white participants were still very proud of their own language (Afri-

\section{Table 1}

Guidelines for the Interpretation of El Scores

\begin{tabular}{ll}
\hline Scores & Guidelines \\
\hline $130+$ & Remarkably high: Atypical well-developed emotional and social capacity. \\
$120-129$ & Very high: Very well-developed emotional and social capacity. \\
$110-119$ & High: Well-developed emotional and social capacity. \\
$90-109$ & Average: Average emotional and social capacity. \\
$80-89$ & Low: Under-developed emotional and social capacity. \\
$70-79$ & Very low: Very under-developed emotional and social capacity. \\
Below 70 & Remarkably low: Atypical poor emotional and social capacity.
\end{tabular}


Table 2

Enhancing Trustworthiness

\begin{tabular}{ll}
\hline Strategies & Description of activities \\
\hline Prolonged fieldwork & Data gathering occurred in four phases over a period of five months. \\
Multi-method strategies & $\begin{array}{l}\text { The study made provision for triangulation and crystallisation at data gathering and anal- } \\
\text { ysis by combining quantitative and qualitative techniques. }\end{array}$ \\
Verbatim reporting of responses & $\begin{array}{l}\text { Conversations during focus group interviews and semi-structured interviews were re- } \\
\text { corded verbatim and then transcribed. Afrikaans was used as medium of communica- } \\
\text { tion. }\end{array}$
\end{tabular}

Low-inference explanations

Mechanical data gathering

Presentation of negative and/or contradictory information

Use of an external coder

Selective use of data was avoided

Participating researcher

Participant review

Inferences that are made have to be supported by sufficient evidence
Explanations and situations were recorded in detail.

All conversations were recorded.

Information was reported in as much detail as possible - also information that could be considered as contradictory to the identified themes.

A competent and experienced external coder revised and assessed the entire project.

Data were not used to falsely verify findings. The external coder assisted in this regard.

A reflection journal was used to note and test perceptions and assumptions so as to ensure that the responses given by the participants were understood correctly.

The participants got the opportunity to determine whether the results and the inferences that were made, were accurate. Misunderstandings were cleared up and/or concepts discussed with the participants before the data was interpreted.

Inferences were only made provided that they could be supported by collected data.

Note. Adapted from Creswell, 2003; McMillan \& Schumacher, 2001.

kaans), culture and religion and regarded these as core components of their identity. All participants indicated that they experienced no problems negotiating their own identity. They - just like the participants in Dolby's (2002) study - showed a fear of black violence and economic progress: They are trying to be better than us (Annet $\left.{ }^{5}\right)$. They are always trying to compete with us ... clothes, cell phone ... school work (Charlene). They must always have better stuff than us (Rika). It also appeared that most participants considered leaving the country after they had left school, as stated by (for example) Gerhard: That's why I can't wait to leave school . . . to get out of this country.

It appeared that the black participants found themselves in different phases of racial identity development and that there was no correlation between the participants' adjustment and functioning in the school and their apparent phase of racial identity development. For instance, both Sasha (who had a very strong racial identity) and James (who found himself in the first phases of racial identity development) seemed to be very successful in adjusting and functioning in their white school context. All participants nevertheless indicated that they (regardless of their apparent phase of racial identity development) had been compelled to conform to a dominant white culture in order to fit in, and the majority of participants agreed that they were two different people - one at home and one at school. Rosy summarised the situation well:

Because when you are here now ... then you have to look white ... Sometimes when we are in white schools ... it is the influence of the other white children ... then we change ... then we already live like them ....
White participants' experience/perception of a black school context

The participants indicated that all of them did not necessarily experience High School A in the same way. Their responses to the question of how they were experiencing the school ranged from terrible (Annet) to it's quite easy-going ... there's not really any snobbishness here (Rika). Language was identified as the biggest obstacle within the school context. For example, the participants indicated that they were having difficulty keeping up with the English, and they complained that some of the (black) teachers simply talked in their own languages. Besides the language issue, it seems that cultural differences (in respect of personal space, the volume of conversations, punctuality and discipline) were also a problem, for example:

They push against you and everything . . . It was very ... how can one say ... 'uncomfortable'.. Yes, and I think this is simply how they are . . . Because we are not used to pushing and shoving and clamour and noise and all . . . but when you come here, then sometimes you also have to push and shove to get to your next class on time ... (Rika).

There seemed to be a strong feeling of solidarity among the white learners in the black school context, and hardly any interaction occurred between the white and black learners. For example, the white participants indicated that they formed their own little group, as Gerhard put it: Listen, we do not notice the difference between black and white but ... the only place where you will see the difference is ... there are the whites and ... the whites are here and the blacks are there. Despite the fact that the white learners were the minority group in High School A, they still seemed to hold a superior view of them- 
Table 3

General Themes and Subthemes

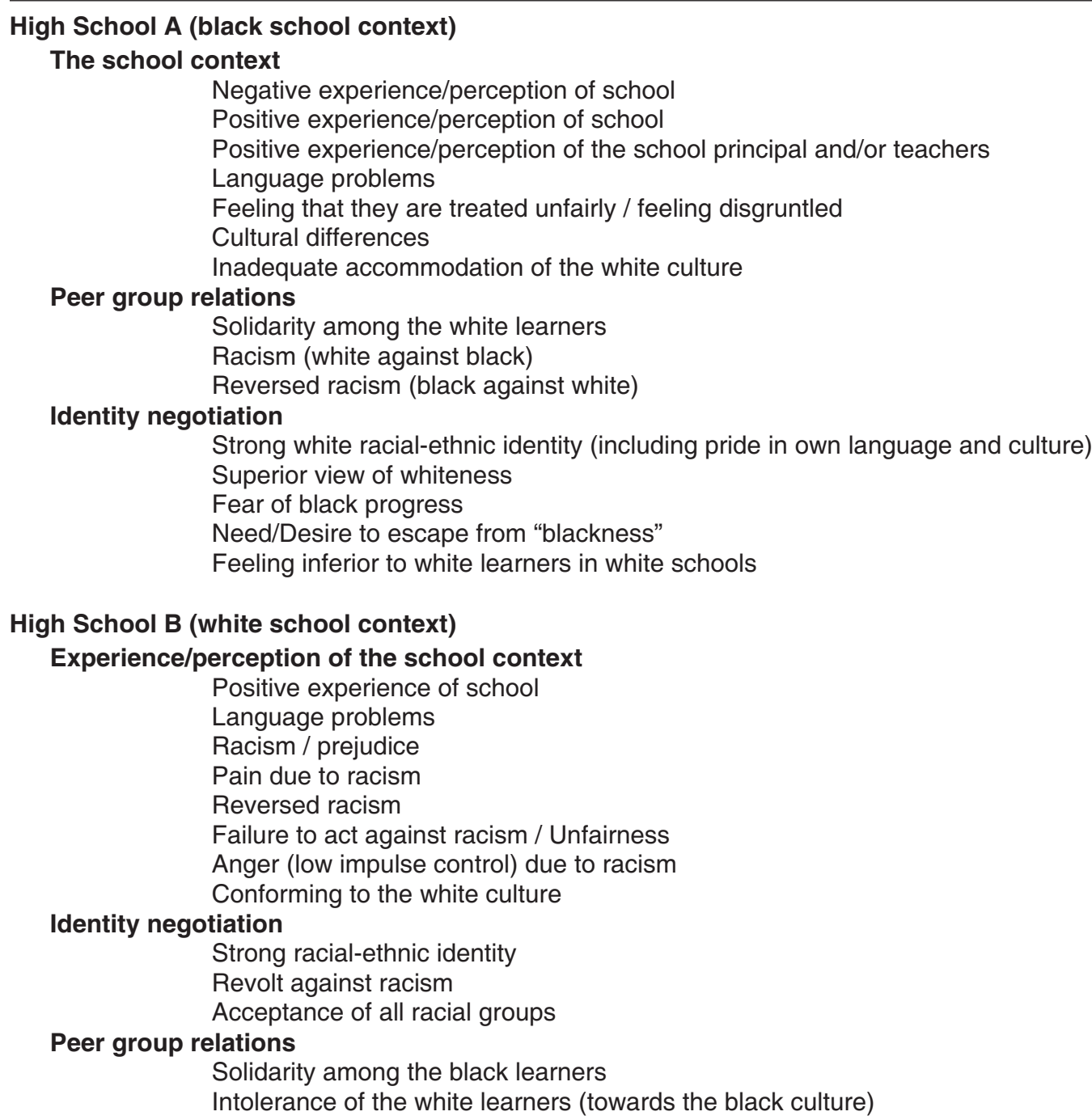

selves and (though subtly) still had a racist attitude towards the black learners. For example, during a focus group session the participants declared themselves strongly against interracial relationships:

I suppose it's not wrong . . . (because at least then there's someone to do the dishes), but .. to go out with a black girl.. our parents have still lived through the apartheid years. They believe that . . . they believe that they are dirty, or something like that ... I believe that it is not right to mix with a person of colour ... No man, if you're white, take a white chick! (Gerhard)

\section{Black Participants' Experience/Perception of a White School Context}

Although most black participants indicated that Afrikaans as medium of instruction posed no problem to them, it transpired from conversations with the teachers that most participants indeed had difficulty with it. Yet, it seemed that for most participants the exposure to racism, discrimination and prejudice offered the biggest challenge. For example, participants indicated that derogatory names such as "houtkoppe", "kaffers" or "meide" were regularly used in their presence, they were often told to "go back to the township" and they regularly had to listen to remarks such as "julle swartes /you blacks.." or "talk to your nation".

Khulile summarised her experience of a white school context as follows:

When you are in a white school . . then people see you as different ... not like them, because you are of another colour.. not like them. They see you as a ... perhaps a monster or something... and they just try to ... push you down ... so that you can perhaps feel bad ... that you can just perhaps leave the school .... .

It also seemed that racism was not restricted to remarks only, but included prejudice. Rosy related for example that she was constantly followed when she worked in the tuck shop. And the children ... they do not wish to touch you ... If you accidentally touch the child ... then they wipe themselves off (demonstrated this as if she was wiping off something dirty). James remarked that he had been falsely accused of theft twice - once while he was working in the tuck shop (the man said he knew it 
wasn't me ... but the lady really insisted that it was ... the non-white working here) and on another occasion when the cell phone of one of the learners in his class was stolen.

All participants indicated that most teachers neglected acting against racism and that they were usually encouraged to "simply leave/ignore it".

\section{The Correlation Between Ei and Participants' Identity Negotiation}

While an insignificant correlation manifested between EI and the identity negotiation of black participants, no such correlation manifested among white participants.

\section{The Correlation Between El and Participants' Adjustment and Functioning in a Majority School Context}

Despite the fact that some of the El scores achieved by participants did not correlate positively with their adjustment and functioning in their school contexts, there generally seemed to be a high, positive correlation between the latter and participants' El.

\section{Black School Context: Annet ${ }^{6}$}

The high-average score $^{7}$ that Annet achieved on the Intrapersonal scale (105) appeared to concur with the qualitative data. It seemed that she could fairly easily share her feelings (with her mother and best girl friends), but that she sometimes struggled to communicate her emotions to individuals with whom she was in conflict. The very high score that she achieved on the Interpersonal scale (120) concurred only to a limited extent with the information that had been gained from the individual interviews; such a score implies superior interpersonal skills, whereas the truth was that she was being rejected by her peer group (she indicated for example that she was unpopular and that she was constantly being mocked and ridiculed). Of course, the possibility of her having answered the questions according to her perception of the relationships with her best girl friends cannot be excluded, seeing that, within the relationships concerned, she could apparently be regarded as a good listener who was able to act emphatically towards her friends (e.g., . . . whenever my friend is sad, I say to her. . "come tell me what is wrong" and then I always try to console her). The average score that she achieved on the Stress Management scale (97) appeared to correspond with the information gained from the qualitative data. It seemed, for example, that she was fairly able to control her emotions (she indicated inter alia that she would not hit anybody), that she sometimes got angry and did not always know how to express these emotions effectively-which led to her merely crying with rage. Annet's low-average score on the Adaptability scale (94) showed that although her problem-solving skills were average, there was still room for improvement. It was clear from the individual interviews that Annet did not always know how to solve problems and that she often tried not to think about them (denial). Her high score on the General Mood scale (117) also seems to concur with the information gained from the individual interviews, since she described herself inter alia as a very optimistic and happy person. When all this information is taken into account, it seems as if Annet is coping fairly well with the everyday demands made on her by the school-as is confirmed by her high-average Total EQ (106) ${ }^{8}$.

\section{White School Context}

The low score that James achieved on the Intrapersonal scale (82) correlates strongly with the information that emerged from the qualitative results, which showed that he found it very difficult to communicate his emotions (for example, he indicated that he knows about putting on a mask, because when I really feel like ... crying, then I think by myself, no, I'm not going to cry.. l'll smile first ... ). Nevertheless, it seemed that James was very successful in his interpersonal relationships-probably more than was indicated by his average score on the Interpersonal scale (103) (according to the head of his grade he drew the largest number of votes in the RSC-election, while all his teachers described him as very popular with his peer group). The possibility of this score having been affected negatively by his fear of rejection can, however, not be excluded (e.g. .. if the children were to know what all my issues are. . . I do not think they will accept me like that). James indicated that he managed to control his emotions very well, which concurs with the very high score that he achieved on the Stress Management scale (127). His emotional control had apparently developed over the past number of years. For example, he indicated that in primary school he had been known as the fighter boy, but that presently he was completely ignoring his emotions pertaining to racism and preferred to keep up a front in school (e.g., I take life as a joke and then I manage to cope... They [the other participants] take it seriously when they [the white learners] call you "kaffer" . . . But I take it as a joke... .).

Although this defence mechanism can hardly be regarded as ideal, it seemed to help James adapt and function very well in his white school context. In addition to the fact that he was vice-head boy, the theatre group as part of which he acted and for which he was the producer, was chosen to take part in the countrywide ATKV final at Aardklop 2009. We are of the opinion that the evaluation of his defence mechanism (denial) can also be approached from another perspective, namely that it does not necessarily have to have a negative effect on the development and functioning of an individual. (The same applies to Annet and Rika in High School A where the defence mechanism mentioned also seemed to help them to escape from difficult circumstances-within and outside of the school context.) The high score that James achieved on the Adaptability scale (116) was confirmed in the qualitative results, since both he and his teachers indicated that he was very successful in solving problems. Although it was clear from the focus group and individual interviews that he was generally a very hardworking and optimistic person, his average score on the General Mood scale (95) was probably affected negatively by his dissatisfaction with his physical build (e.g., . . one of the James's that I probably 'act' every day, he's probably in love with himself, I am not ... I I would have liked to be a little leaner). It nevertheless seemed that James's high Total EQ (111) corresponded with his good adjustment and successful functioning in the school.

In conclusion, it appears that in most cases there is a high correlation between the El of participants (in both school contexts) and their adjustment and functioning in these schools.

\section{Significance of El in this Study}

\section{El and Psychological Health}

Research indicating that individuals with a high El display higher levels of effective stress management, problem solving and adequate mood regulation (Bar-On, 2001; Nikolaou \& Tsaousis, 2002) was generally confirmed in this study. For example, it seemed that James and Bennie (who achieved the highest Total EQ scores in each school context) were best able to solve problems and apply emotional control, while Rika and 
Werner (who obtained the lowest EQ scores in High School A) experienced difficulty in this regard.

\section{El and Interpersonal Relationships}

The positive correlation between El and interpersonal relationships was largely demonstrated in this study. Although Annet (as mentioned earlier) achieved a very high score on the Interpersonal scale (120) despite the fact that she was rejected by her peer group, and Rika, who achieved an average score on the Interpersonal scale (93) got along with her peer group (white and black) much better, it was possible to observe a positive correlation between the El and interpersonal relationships of the other participants in High School A and B.

\section{Other Factors}

There are other factors that may potentially play a role in the choice of a majority school context and the adjustment and functioning within this context.

Victimisation/rejection in (previous) white schools. The qualitative results showed that Annet, Charlene and Rika had experienced much victimisation and rejection in their (predominantly white) primary schools, while Werner indicated that he also suffered such feelings in the high school from which he had been expelled. The participants' fear of rejection in white schools and the feelings of inferiority that were associated with it, could (in our view) play an important role in their choice to "stay behind" in High School A despite the migratory trend of white learners from former white schools.

Home environment/domestic circumstances. In addition to the above, some participants apparently found themselves in difficult domestic circumstances. For example, it transpired that Charlene and Gerhard had earlier been exposed to physical as well as verbal abuse and that Rika, Gerhard and James did not have a positive father figure in their lives at present. The effect of these on their personal, social and emotional development could therefore not be ignored.

The role of faith. Although this theme emerged only with Charlene (High School A) and Sasha (High School B), its impact on their self-acceptance, interpersonal relationships and general mood could be observed very clearly. The possible ef fect of their faith (and the Christian value system that accompanied it) on (their) El should therefore not be denied.

The role of achievement. It became clear that in addition to $\mathrm{El}$, achievement also played an important role in the adjustment and functioning of a racial minority group in a majority school context. For example, Gerhard and Bennie indicated that they were members of the school's first rugby team, while Rika excelled academically (these participants adapted and functioned in school much better than did for example Annet, Charlene and Werner).

The same trend could be observed with regard to High School B. For instance, it turned out that Alfred, James and Sasha adapted in school much better and also had more friends than did Khulile and Tebogo. It is, however, necessary to mention that Alfred was an excellent rugby player while Sasha and especially James excelled in the cultural and leadership field.

The support of parent(s). It transpired from the focus group and individual interviews that most participants (with the exception of Gerhard who perceived his parents as absent) were receiving adequate support from one or more parent. Thus, the possible role that parental support plays in the adjustment and functioning of the participants within a majority school context cannot be underestimated, considering the inadequate support that (especially the black) participants receive in their school context (Coie et al., 1993; Doll \& Lyon, 1998; Dryfoos, 1997; Durlak, 1998; Mayer \& Salovey, 1997; Zeidner, Roberts \& Matthews, 2002).

A major limitation of the study is that only two schools were involved in the study. The way in which the specific participants adjust, function and negotiate their own identity within these contexts is not necessarily representative of the way in which it is done by all the members of racial minority groups within these schools, or in other majority school contexts.

\section{Conclusion}

The educationally significant impact of El in the adjustment and functioning of racial minority groups in majority school contexts was illustrated in this study. Through our collection and analysis of qualitative data, we have shown the problems that participants experience in different racial-minority or racial-majority schools. Social acceptance of each other, for instance, is still far from adequate and is cause for great concern, inter alia because we concur with the view expressed by Mpofu and Watkins (1997) that learners' lack of social acceptance at school for perceived value of instruction because greater within-class social participation may be related to raised levels of academic achievement with teachers and peers.

Furthermore it was shown that racial integration in both high schools actually occurred in name only; most participants chose to mingle within their own racial groups and the black participants in High School B were exposed to racism, discrimination and prejudice on a regular basis. In our view, this study can be considered a micro-cosmos of South Africa. Despite the necessary steps taken and implemented by government in order to oppose racism in the country and promote racial integration in schools, it seems that the consequences of apartheid will remain in our midst for a very long time to come. We also came to realise why race (still) enjoyed so much attention in the literature and why race-related studies elicit so much reaction - people can say what they want ... racism may perhaps be more subtle, but it is still very much alive! (James). The irony is that the situation will not change unless South Africans (really) meet this fact head-on and start talking about it more openly and honestly and actively try to do something about this displeasing situation. Further research in this field seems essential. In this regard, we strongly agree with the recommendation by Mpofu, Thomas, and Chan (2004) that minority students' social acceptance in multiracial school settings should be investigated and that observational studies of the impact of institutional practice on learners' perceived social competence should be encouraged.

Our findings may have implications for the integration of schools. Firstly, pre-service teachers will probably benefit from the introduction of emotional intelligence training programmes into their curricula at teacher education institutions. Secondly, in-service teachers may need to be introduced to training in this field as well, and the National Department of Education could be expected to take the lead in this regard. Thirdly, all persons involved with learners' teaching and learning, irrespective of whether they be prospective or practising teachers, probably need to be trained in anti-bias programmes so as to enable them to not only identify and deal with their own bias, but also to act as role models in our racially diverse classrooms and to facilitate this skill among the myriad learners in our schools. Lastly, it seems essential to find some way to find a safe and financially viable manner to redeploy white teachers to predominantly black schools and vice versa to facilitate deeper understanding of the 'other', to break down bridges be- 
tween groups of people from different racial backgrounds and, eventually, to contribute to the creation of a non-racist society in post-apartheid

We sincerely hope that our article adds to the available knowledge base in this field by exploring and highlighting the social contradictions that exist in most South African social institutions. After all, individual identities, negotiated as they may be, are the cornerstone for a national identity. Schools can and should help to build health emotional identities by, for example, offering spaces where students share past and present experiences and navigating weaknesses of the past and present that threaten their emotional identities.

\section{References}

Akos, P., \& Ellis, C. M. (2008). Racial identity development in middle school: A case for school counselor individual and systemic intervention. Journal of Counseling Development, 86, 26-33.

Alvarez, A., Juang, L., \& Liang, C. (2006). Asian Americans and racism: When bad things happen to "model minorities". Cultural Diversity \& Ethnic Minority Psychology, 12, 477-492.

Bar-On, R. (1997). Bar-On Emotional Quotient Inventory: Technical manual. Toronto, Canada: Multi-Health Systems.

Bar-On, R. (2001). Emotional intelligence and self-actualization. In J. Ciarrochi, J.P. Forgas, \& J.D. Mayer (Eds.), Emotional intelligence in everyday life: A scientific enquiry (pp. 82-97). Philadelphia, PA: Psychology Press.

Bar-On, R. (2006). How important is it to educate people to be emotionally intelligent, and can it be done? In R. Bar-On, J.G. Maree, \& M. Elias (Eds.), Educating people to be emotionally intelligent (pp. 1-16). Sandton, South Africa: Heinemann.

Bar-On, R., \& Parker, J. D. A. (2000). Bar-On Emotional Quotient Inventory: Youth Version. Technical manual. Toronto, Canada: Multi-Health Systems.

Bar-On, R., Tranel, D., Denburg, N. I., \& Bechara, A. (2003). Exploring the neurological substrate of emotional and social intelligence. Brain, 126, 1790-1800.

Bennett, C. I. (1999). Multicultural education: Theory and practice (4th ed). Boston, MA: Allyn \& Bacon.

Chavous, T., Bernat, D., Schmeelk-Cone, K., Caldwell, C., Kohn-Wood, L., \& Zimmerman, M. (2003). Racial identity and academic attainment among African American adolescents. Child Development, 74, 1076-1090.

Coie, J. D., Watt, N. F., West, S. G., Hawkins, J. D., Asarnow, J.R., Markman,. . . \& Long, B. (1993). The science of prevention: A conceptual framework and some directions for a national research program. American Psychologist, 48, 1013-1022.

Creswell, J. W. (2003). Research design Qualitative, quantitative and mixed methods approaches (2nd ed.). Thousand Oaks, CA: Sage.

Creswell, J. W. (2007). Qualitative inquiry and research design: Choosing among five approaches (2nd ed.). London: Sage.

Cross, W. E. (Jr). (1971). The Negro-to-Black conversion experience. Black World, 20, 13-27.

Cross, W. E. (Jr). (1991). Shades of black: Diversity in African American identity. Philadelphia, PA: Temple University.

Cushman, P. (2000). White guilt, political activity, and the analyst: Commentary on paper by Neil Altman. Psychoanalytic Dialogues, 10, 607-618.
Cushner, K., McClelland, A., \& Safford, P. (2006). Human diversity in education: An integrative approach (5th ed.). New York: McGraw-Hill.

Denzin, N. K., \& Lincoln, Y.S. (1998). The landscape of qualitative research. London: Sage.

Dolby, N. (2001). White fright: The politics of white youth identity in South Africa. British Journal of Sociology of Education, 22, 5-17.

Dolby, N. (2002). Making white: Constructing race in a South African high school. Curriculum Inquiry, 32, 7-29.

Doll, B., \& Lyon, M. A. (1998). Risk and resilience: Implications for the delivery of educational and mental health services in schools. School Psychology Review, 27, 348-363.

Dryfoos, J. G. (1997). The prevalence of problem behaviors: Implications for programs. In: R.P. Weissberg, T.P. Gullotta, R.L. Hampton, B.A. Ryan \& G.R. Adams (Eds.). Healthy children 2010: Enhancing children's wellness (pp. 17-46). Thousand Oaks, CA: Sage.

Du Plooy, J., \& Swanepoel, Z. (1997). Multicultural education: Problems faced by minority groups in schools. Acta Academica, 29, 129-153.

Durlak, J. A. (1998). Common risk and protective factors in successful prevention programs. American Journal of Orthopsychiatry, 68, 512-520.

Erasmus, P. (1999). The accommodation of the black grade nine learner in a traditionally white school (Unpublished doctoral thesis). Pretoria: University of Pretoria.

Erikson, E. H. (1968). Identity youth and crisis. New York: Norton.

Grantham, T. G., \& Ford, D. Y. (2003). Beyond self-concept and self-esteem: Racial identity and gifted African American students. High School Journal, 87, 18-29.

Harber, C. (1998). Desegregation, racial conflict and education for democracy in the new South Africa: A case study of institutional change. International Review of Education, 44, 569-582.

Helms, J. E. (1995). An update of Helms' White and People of Color racial identity models. In J.G. Ponterotto, J.M. Casas, L.A. Suzuki, \& C.M. Alexander (Eds.). Handbook of multicultural counseling (pp. 181-198). Thousand Oaks, CA: Sage.

Jackson, R. L., \& Heckman, S. M. (2002). Perceptions of white identity and white liability: An analysis of white student responses to a college campus racial hate crime. Journal of Communication, June, 434-450.

Jansen, J. (2004). Race, education and democracy after ten years - How far have we come? Speech prepared for the Institute for Democracy in South Africa (IDASA).

Kaschula, R. H., \& Anthonissen, C. (1995). Communicating across cultures in South Africa: Toward a critical language awareness. Johannesburg, South Africa: Hodder \& Stoughton.

Kendall, D. (1997). Race, class and gender in a diverse society: A text-reader. Boston, MA: Allyn \& Bacon.

Kriel, H. A. (2000). Intergroepverhoudings in hoërskole. (Inter-group relationships in secondary schools.) (Unpublished master's dissertation). Pretoria: University of Pretoria.

Machaisa, P. R. (2004). The experiences of learners in former white schools (Unpublished master's dissertation). Pretoria: University of Pretoria. 
Maree, J. G., \& Ebersöhn, L. (2002). Emotional intelligence and achievement: Redefining giftedness? Gifted Education International, 16, 261-273.

Mayer, J. D., Caruso, D. R., \& Salovey, P. (1999). Emotional intelligence meets traditional standards for an intelligence. Intelligence, 27, 267-298.

Mayer, J. D., \& Salovey, P. (1997). What is emotional intelligence? In P. Salovey \& D. Sluyter (Eds.), Educational implications (pp. 3-34). New York, NY: Basic Books.

McDermott, M,. \& Samson, F.L. (2005). White racial and ethnic identity in the United States. Annual Reviews Sociology, 31, 245-261.

McMillan, J. H., \& Schumacher, S. (2001). Research in education. A conceptual introduction (5th ed.). New York: Addison Wesley Longman Inc.

Mpofu, E., Thomas, K., \& Chan, F. (2004). Social competence in multicultural schools: Effects of ethnic and gender differences. International Journal of Psychology, 39, 169-178.

Mpofu, E., \& Watkins, D. (1997). Self-concept and social acceptance in African multiracial schools: A test of the insulation, subjective culture and bicultural competence hypotheses Cross-Cultural Research, 31, 331-355.

Msila, V. (2005). The education exodus: The flight from township schools. Africa Education Review, 2, 173-188.

Nieto, S. (2000). Affirming diversity: The sosiopolitical context of multicultural education (3rd ed.). Boston, MA: Addison Wesley Longman.

Nikolaou, I., \& Tsaousis, I. (2002). Emotional intelligence in the workplace: Exploring its effects on occupational stress and organizational commitment. The International Journal of Organizational Analysis, 10, 327-342.

Norton, J., \& Baker, P. M. (2007). The experience of whiteness among students at a BC university: Invisibility, guilt, and indifference. BC Studies, 153, 35-72.

Pahl, K., \& Way, N. (2006). Longitudinal trajectories of ethnic identity among urban Black and Latino adolescents. Child Development, 77, 1403-1415.

Phinney, J. S. (1989). Stages of ethnic identity development in minority group adolescents. Journal of Early Adolescence, 9, 34-49.

Polson, E. (1996). Die effek van 'n stereotipe verminderingsprogram van hoërskool-leerlinge [The effect of a stereotype decrease programme for high school learners]. Master's dissertation, Pretoria, University of Pretoria.

Saklofske, D. H., Austin, E. J., \& Minski, P. S. (2003). Factor structure and validity of a trait emotional intelligence measure. Personality and Individual Differences, 34, 1091-1100.

Sellers, R. M., \& Shelton, J. (2003). The role of racial identity in perceived racial discrimination. Journal of Personality and Social Psychology, 84, 1079-1092.

Suchet, M. (2007). Unraveling whiteness. Psychoanalytic Dialogues, 17, 867-886.

Sue, D. W. \& Sue, D. (1990). Counselling the culturally different: Theory and practice (2nd ed.). Kenwyn, South Africa: Juta.

Taylor, G. J. (2001). Low emotional intelligence and mental illness. In J. Ciarrochi, J.P. Forgas, \& J.D. Mayer (Eds.), Emotional intelligence in everyday life: $A$ scientific enquiry (pp. 67-78). Philadelphia, PA: Psychology Press.
Tihanyi, K. (2007). Racial integration in the USA and South Africa: Lessons in a comparative perspective. International Journal of Inclusive Education, 11, 177-197.

Vandeyar, S. (2007). Shifting selves: The emergence of new identities in South African schools. International Journal of Educational Development, 28, 286-299.

Van Rooyen, J. (2002). Training manual: Bar-On Emotional Quotient Inventory. Randburg, South Africa: JVR \& Associates.

Wakefield, W. D., \& Hudley, C. (2007). Ethnic and racial identity and adolescent well-being. Theory into Practice, 46, 147-154.

Zeidner, M., Roberts, R. D., \& Matthews, G. (2002). Can emotional intelligence be schooled? A critical review. Educational Psychologist, 37, 215-231.

Zirkel, S. (2004). What will you think of me? Racial integration, peer relationships and achievement among white students and students of color. Journal of Social Issues, 60, 57-74.

\section{Endnotes}

${ }^{1}$ The term "negotiation" points to the "process of development" (of an identity).

${ }^{2}$ Despite the use of the female form, both sexes are implied.

${ }^{3}$ We accept that the scope and generalisation value of the study is limited and wish to emphasise that the problem statement has been investigated and interpreted within the context of the study.

${ }^{4}$ The reader has to note that the inferences made are of a qualitative nature and that the participants' levels of identity development as such were not measured.

${ }^{5}$ Pseudonyms were used throughout.

${ }^{6}$ In these sections we focus each time (for the sake of brevity) in more detail on an analysis of one participant's response so as to illustrate the possible general similarities and differences between the school-related experiences and perceptions of black and white participants and aspects of their El.

${ }^{7}$ For the purpose of our study, the following descriptions (with regard to El scores of 90-109) were used: 90-94 = "low-average"; 95-104 = "average"; 105-109 = "high-average".

${ }^{8}$ The agreement between this score and the qualitative data is for the aim of this study determined by how successful the participant seems to be in coping with (school) environmental demands (as became clear from the qualitative data analysis), as against the Total EQ that the he/she achieved. 